\title{
Evaluation of surgical nurses' attitudes concerning patient safety
}

\author{
Ali Şahin ${ }^{1}$
}

Fatma Ayhan ${ }^{2}$

Serife Kursun ${ }^{3}$

\begin{abstract}
The present study was designed as a descriptive study to evaluate the attitudes of surgical nurses concerning patient safety. The study included 123 nurses, who have been working in the operating rooms of the hospitals in Karaman, Konya for at least one year and were voluntary to participate in the study. Data collection tools included a questionnaire to inquire demographic characteristics of surgical nurses, and "Safety Attitudes Questionnaire (SAQ) -Operating Room Version" to evaluate their attitudes concerning patient safety. The mean scores obtained from SAQ sub-dimensions were between $42.12 \pm 16.82$ and $69.07 \pm 24.44$, whereas the mean score of SAQ total was $59.11 \pm 13.29$. Statistically significant difference was determined between the mean SAQ total score and age, weekly working hours, duration of working in the operating room, resting status, receiving in service training, and training about patient safety. The present study will enhance patient safety in operating rooms by providing an improvement in communication among health workers and in team collaboration, regulating working hours, and scheduling training programs to establish an opinion about worker safety and patient safety.
\end{abstract}

Key words: Opinion of patient safety; Operating room; Patient safety; Surgery; Surgical patients

\section{Introduction}

Patient safety is defined as the prevention of health service-related errors and elimination or reduction of patient injury caused by health service-related errors. In the health sector, the concept reducing the losses due to medical errors and in addition, creating patient safety awareness by monitoring and recording the issues that threat patient and worker safety has recently gained

\footnotetext{
${ }^{1}$ Ali Şahin, Department of pharmacology, Prof. Dr., Karamanoglu Mehmetbey University, Health College, Karaman, alisahin@kmuedu.tr

${ }^{2}$ Fatma Ayhan, Department of Surgical Disease Nursing, Lecturer, Karamanoglu Mehmetbey University, Health College, Karaman, f.kucuksumbul@gmail.com.

${ }^{3}$ Şerife Kurşun, Department of Surgical Disease Nursing, Assist. Prof. D., Selçuk University, Health Sciences Faculty, Department of Surgical Disease Nursing, serifekursun@hotmail.com
} 
Şahin, A., Ayhan, F., \& Kurşun, Ş. (2015). Evaluation of surgical nurses' attitudes concerning patient safety. International Journal of Human Sciences, 12(1), 1537-1546. doi: 10.14687/ijhs.v11i1.2879

increasing importance and the concept of "Patient Safety Opinion" has become a matter of debate (Alcan, 2012; Sayek, 2011).

Medical errors are the most important factors that threat patient safety. Medical errors attract attention due both to harmful impacts on patients and gradually increasing prevalence (Akalın, 2007; Buetow, 2005). World Health Organization (WHO) reports an injury or death due to unsafe medical applications in one out of every 10 patients (WHO, 2005). Absence of a structured patient safety system yet in Turkey suggests that the risk is higher (Alcan, 2012).

Whilst medical errors are likely to be encountered in any field of health services, they are more prevalent in the operating rooms. Operating rooms are the places with various risks that influence the patient and workers' health including complex internal structure, stressful working environment, advanced technological devices and tools, various surgical techniques, and long and mostly unpredictable working hours (Buetow, 2005; Göçmen, 2004). Considering that one of each 25 subjects undergoes surgical procedure for at least once in a life time and surgical error occurs in at least one of each 50 patients, it is obvious that operating rooms have a particular importance concerning patient safety (WHO, 2013).

All patient safety practices in an operating room aim at minimizing the error and enhancing well-being of patients so far as possible. However, the probability of errors increases due to inadequate number of qualified health professionals, long working hours, tiredness and inattentiveness, and inconvenient physical conditions of operating room (Alcan, 2012; Berenholtz \& Pronovost, 2007). Factors that are defined as operating room-originated medical errors and threat patient safety include wrong side, wrong organ, wrong surgical intervention, leaving foreign body, drug administration errors, infection-related health care risks, falls, burnt due to the surgical procedure and environment, inability to identify high risk patients, and pressure injuries (Alcan, 2012; Aslan, 2009).

Declaration on Patient Safety from International Council of Nurses (ICN) emphasized that patient safety is the main issue of patient care and quality of nursing services. Nurses are involved in patient safety in all fields of health care (Alcan, 2012). Whilst Banister et al (1996), mentioned that nurses have been trained in the way to give safe and perfect care and that well-trained nurses do not make mistakes, Feeg (2001) defines professionalism in nursing as "being good and doing the good". Leadership of a nurse is the main issue in effective care and achieving successful outcomes. Advocacy, creating a safe environment, research, involving in the formation of health policies and in the management of health systems, and education is the important roles of nursing. Among these roles, advocacy and creating a safe environment in particular come into prominence (Catalano, 2005). The fact that operating rooms are the places where the patients are extremely 
Şahin, A., Ayhan, F., \& Kurşun, Ş. (2015). Evaluation of surgical nurses' attitudes concerning patient safety. International Journal of Human Sciences, 12(1), 1537-1546. doi: 10.14687/ijhs.v11i1.2879

unguarded because of the nature of operating rooms lays a great burden on the nurses in line with their vocational philosophy, since surgical nurse needs to protect the patient, who is under anesthesia with impaired tissue integrity, against potential medical errors. While prevention of these medical errors could be lifesaving, misapplications may have life ending consequences (Alcan, 2012).

In the light of this information, this study was planned to evaluate surgical nurses' attitudes concerning patient safety and related factors, considering that it would contribute to provision and maintenance of safe and effective treatment and care in the operating rooms.

\section{Materials and methods}

\section{Type, place and date of research}

This descriptive study was conducted in surgery departments of Karaman State Hospital, Konya State Hospital, Beyhekim State Hospital, Konya Training and Research Hospital, Selçuk University Faculty of Medicine Teaching Hospital, and Necmettin Erbakan University Meram Faculty of Medicine Teaching Hospital between 1 October and 30 December 2013.

\section{Study universe and sample}

There are a total of 134 surgical nurses, of whom 30 were from Karaman State Hospital, 50 were from Konya Training and Research Hospital, 24 were from Beyhekim State Hospital, 14 were from Selçuk University Medical Faculty Teaching Hospital, and 66 were from Necmettin Erbakan University Meram Medical Faculty Teaching Hospital. For the study sample, the nurses, who have been working in an operating room, were not off duty or on sick leave within the study period, and agreed to participate, were recruited.

\section{Data collection}

In this study, a descriptive information form, which has been structured in line with the literature (Andsoy et al., 2012; Önler, 2010) was used to assess descriptive characteristics of the workers, and "Safety Attitudes Questionnaire (SAQ)-Operating Room Version" was used to assess attitudes concerning patient safety.

Descriptive information form; consists of 11 questions to identify socio-demographic and professional characteristics (age, gender, marital status, education status, year of graduate, position at working place, working hours, experience at the hospital they have been working, presence of inservice-training program in the institute, and education regarding patient safety) of the workers. 
Şahin, A., Ayhan, F., \& Kurşun, Ş. (2015). Evaluation of surgical nurses' attitudes concerning patient safety. International Journal of Human Sciences, 12(1), 1537-1546. doi: 10.14687/ijhs.v11i1.2879

Safety Attitudes Questionnaire (SAQ)-Operating Room Version: was developed by Sexton et al. (2006) and evaluates the attitudes of operating room staffs concerning patient safety. SAQ measures the attitudes of staffs in 6 fields of patient safety and is used by the organizations to compare themselves with other organizations; to plan interventions aimed at developing safety attitudes; and to assess the efficacy of these interventions (Sexton et al., 2006). Validity and reliability for Turkish version was done in 2010 by Önler, and Cronbach alpha confidence coefficient was found 0.92 for total scale and between 0.50 and 0.82 for sub-dimensions (Önler, 2010).

For the answers, 5-point likert scale was used ( $1=$ Fully disagree, $2=$ Disagree $3=$ Undecided $4=$ Fully agree $5=$ Agree). The score was converted into the system of hundreds as follows: $1=0$, $2=25,3=50,4=75$, and 5=100 (Makary, 2007). Answers given to each question of the questionnaire are summarized, divided by the number of items, converted into the system of hundreds, and a point between 0 and 100 is obtained. Calculation of a point obtained for a worker from team collaboration sub-dimension has been formulated as follows: in addition to the questionnaire, each version of the questionnaire includes likert-type open-ended questions $(1=$ very poor, 2=Poor $3=$ Moderate $4=$ Good $5=$ Very good) that inquire the collaboration and communication among workers and ask for opinion concerning development of patient safety (Sexton et al., 2006).

\section{Pretest}

In order to evaluate understandability and applicability of data collection forms, 10 surgical nurses from different hospitals underwent pretesting and the questionnaire form was finalized.

\section{Data analysis}

Data were summarized using number, percentage, mean and standard deviation. The relation between the variables and the questionnaire was evaluated by t-test, Kruskal Wallis test (further analyses: Mann Whitney $\mathrm{U}$ test with Bonferroni Correction and Tukey), and F test (further analysis: Tukey).

\section{Ethical issue}

Written authorization was obtained from the head physician of the hospitals (Karaman State Hospital, Konya Training and Research Hospital, Beyhekim State Hospital, Selçuk University Medical Faculty and Necmettin Erbakan University Meram Medical Faculty) for the study, and verbal permission was obtained from Assoc. Prof. Dr. Ebru Önler, who has done the validity and reliability of the scale, and from the nurses that agreed to participate in the study to use the scale. 
Şahin, A., Ayhan, F., \& Kurşun, Ş. (2015). Evaluation of surgical nurses' attitudes concerning patient safety. International Journal of Human Sciences, 12(1), 1537-1546. doi: 10.14687/ijhs.v11i1.2879

\section{Results}

A total of 123 nurses participated in the present study, which was conducted to evaluate surgical nurses' attitude concerning patient safety.

Of the nurses, $53.7 \%$ were in 20-39 year-age-group, $74 \%$ were female and $42.3 \%$ had an education status of bachelor degree or over (Table 1).

With regard to the professional characteristics of surgical nurses, $68.3 \%$ were permanent staffs and $51.2 \%$ had a mean weekly working time of 40 hours. The mean duration of working in the operating room was $1-5$ years for $42.3 \% ; 85.4 \%$ have been working voluntarily in the operating room; and $63.4 \%$ have inadequate resting time. Of the employees, $78.9 \%$ mentioned that their institute has regular in-service-training program and $66.7 \%$ had received training for patient safety (Table 2).

The mean score that the nurses obtained from sub-dimensions of SAQ changed between 42.12 \pm 16.82 and $69.07 \pm 24.44$, whereas the mean score of SAQ total was 59.11 \pm 13.29 (Table 3).

Comparison between demographic characteristics of operating room staffs and SAQ total score is given in Table 1. Statistically significant difference was determined between the ages of the nurses and safety attitudes, but not between gender and education status. Further analysis revealed a lower total score in the nurses in 18-29 year-age-group as compared to the nurses in the other age groups $(\mathrm{P}<0.05$, Table 1$)$.

Comparison between professional characteristics and total SAQ scores of operating room staffs is given in Table 2. No statistically significant difference was determined between working status, voluntariness to work in the operating room and the mean total score of safety attitude questionnaire $(\mathrm{P}>0.05)$. Statistically significant difference was found between mean score of SAQ total and weekly working hours, duration of working in the operating room, resting status, inservice-training and training about patient safety. Total score was found to be low in the nurses that have been working for more than 40 hours weekly, not having a rest after working, not received in-service-training, and not trained about patient safety as comparerd to the other groups $(\mathrm{P}<0.05)$. The score of total scale was higher in the nurses that have been working for 16 years or longer in the operating room as compared to the nurses working for less than 1 year, 1 to-5 years, and 11 -to- 15 years $(\mathrm{P}<0.05$; Table 2$)$.

\section{Discussion}

The present study found that, mean score of SAQ total was 59.11; mean score of satisfaction with job was 69.07; mean score of team collaboration was 66.03; mean score of safe environment was 63.16; mean score of working conditions was 61.18; mean score of opinion about administration was 56.56; and mean score of stress level assessment was 42.12. Sexton et al. (2006) 
Şahin, A., Ayhan, F., \& Kurşun, Ş. (2015). Evaluation of surgical nurses' attitudes concerning patient safety. International Journal of Human Sciences, 12(1), 1537-1546. doi: 10.14687/ijhs.v11i1.2879

found the mean score of team collaboration 71.7 ; mean score of satisfaction with work 70.1; mean score of safe environment 69.6; mean score of working conditions 57.5; mean score of stress level assessment 54.7; and mean score of opinion about administration 47.6. Hewson (2007) determined the mean score of team collaboration to be 73.55; mean score of satisfaction with work 73.95; mean score of stress level assessment 69.64; mean score of safe environment 66.72; mean score of working conditions 58.97; and mean score of opinion about administration 55.61. In the study conducted by Önler (2010) mean score of SAQ total was 59.22; mean score of stress level assessment was 67.34; mean score of team collaboration was 64.09; mean score of satisfaction with work was 63.21; mean score of safety environment was 55.99; mean score of working condition was 48.42; and mean score of opinion about administration was 45,18. In line with the present study, Sexton et al. (2006) and Hewson (2007) obtained the highest scores from satisfaction with work subdimension. Whilst the lowest score was obtained from stress level assessment subdimension in the present study, Önler (2010) obtained the highest score from this subdimension. The lowest score was obtained from the opinion about administration subdimension in the studies conducted by Sexon et al. (2006), Hewson (2007) and Önler (2010).

With regard to the mean SAQ scores among age groups, the mean score was statistically significantly lower in 18-29 year-age-group as compared to the other age groups. Similar with the results of the present study, Önler (2010) found the mean scores to be significantly lower in 18-29 year-age-group as compared to the other age groups.

The present study found no statistically significant difference between the mean score of SAQ total and gender, education status, working as a permanent or on contract staff, and working voluntarily in the operating rooms. Önler (2010) found no difference between mean score of SAQ total and gender and education status, but determined that SAQ total score was statistically significantly higher in those working voluntarily in the operating room.

Mean score of SAQ total was statistically significantly lower in the nurses working more than 40 hours weekly as compared to those working 40 hours. Rogers et al. (2004) reported that working shifts could exceed 12 hours leading to an increase in the risk of making mistakes. Arda et al. (2007) stated that high number of shifts and excessive tiredness may also unfavorably affect communication process and accordingly patient safety. In contrast, considering weekly working hours, Dursun et al. (2010) and Özmen and Başol (2010) found no significant difference for patient safety.

Mean score of SAQ total was statistically significantly higher in those working in the operating room for longer than 16 years as compared to those working for shorter time. Similarly, Önler (2010) found that mean score of SAQ total was higher in those working for longer than one 
Şahin, A., Ayhan, F., \& Kurşun, Ş. (2015). Evaluation of surgical nurses' attitudes concerning patient safety. International Journal of Human Sciences, 12(1), 1537-1546. doi: 10.14687/ijhs.v11i1.2879

year versus those working for 0-5 years and in those working for longer than 11 years versus those working for 6-11 years.

The present study found that the mean score of SAQ total was higher in those having adequate rest, underwent in-service-training and received training for patient safety. Supporting the results of present study, Önler (2010) found the mean score of SAQ total to be high in those underwent in-service-training. However, no difference was found between those having adequate rest versus not and those received training for patients safety versus not.

Christian et al. (2006) determined that performance was reduced in the operating room staffs having inadequate communication and information flow and high work load leading to unfavorable impact on patient safety; this result is in line with the results of the present study (Christian et al., 2006).

In the light of these findings, the factors such as longer weekly working hours, inadequate resting, not giving in-service-training, and being unable to establish patient safety concept unfavorably influence both the patient's and worker's safety.

\section{Acknowledgements}

This research was supported by scientific research projects of Karamanoglu Mehmetbey University (Project No. 35-M-12).

\section{References}

Akalın, E. (2007). Klinik araştırmalar ve hasta güvenliği. İku Dergisi, 17, 32-35.

Alcan, Z., Tekin, D.E., Civil, S.Ö. (2012). Hasta güvenliği. 1th ed. İstanbul. Nobel tip kitapevleri.

Buetow, S. (2005). Why the need to reduce medical errors is not obvious. Journal of Evaluation in Clinical Practice, 11, 53-57.

Andsoy, I.I., Güngör, T., Nabel., E.B. (2012). Ameliyathane hemşirelerinin yangin güvenliğine karş1 aldığı önlemlerin belirlenmesi: Karabuk ili örneği. Journal of Contemporary Medicine, 2, 87-93.

Arda, H., Ertem, B., Durgun, Y. (2012). Dicle Üniversitesi araştırma hastanesinde çalışan hekim ve hemşirelerin hasta iletişimi konusundaki görüşleri, İstanbul Üniversitesi Florence Nightingale Heşirelik Yüksekokulu Dergisi, 15, 68-74.

Berenholtz, S.M., Pronovost P.J. (2007). Monitoring patient safety. Crit Care Clin, 23, 659-673.

Aslan, F.E. (2011). Ağrı. In: Karadakovan A, Aslan EF, editors. Dahili ve Cerrahi Hastalıklarda Bakım. 2nd ed. Adana, Nobel Kitabevi, pp.145-161.

Banister, G., Hackel, R., Butt, L. (1996). How nurses perceived medication errors. Nursing Management, 27, 31-34.

Catalano, K. (2005). Update on the national patient safetygoals-changes for 2005, AORN Journal, 8 , 336-341.

Christian, C.K., Gustafson, M.L., Roth, E.M., Sheridan, T.B., Tejal, K.G., Kathleen, D., Michael. J.Z., Meghan, M.D. (2006). A prospective study of patient safety in the operating room. Surgery, 139,159-173. 
Şahin, A., Ayhan, F., \& Kurşun, Ş. (2015). Evaluation of surgical nurses' attitudes concerning patient safety. International Journal of Human Sciences, 12(1), 1537-1546. doi: 10.14687/ijhs.v11i1.2879

Dursun, S., Bayram, N., Aytaç, S. (2010). Hasta Güvenliği Kültürü Üzerine Bir Uygulama. Sosyal Bilimler, 8,1-14.

Feeg, V.D. (2001). Another view on professionalism. Pediatric Nursing, 27,220-221.

Hewson, K. (2007). Assessing the safety culture in Tertiary ICU, Intensive care coordination Monitoring unit. Erişim: 30.06.2013,

http://oit.hsnet.nsw.gov.au/five/doc/lectures_presentations/hewson/2007_SAQ_ANZICS_Hew son safety culture.pdf.

Makary, M.A., Mukherjee, A., Sexton, J.B., Syin, D., Goodrich, E., Hartmann, E., Rowen, L., Behrens, D., Marohn, M., Pronovost, P. (2007). Operating room brifings and wrong-site surgery. Journal of the American College of Surgeons, 204, 236-243.

Önler, E. (2010). Ameliyathanede çalışanların hata güvenliğine ilişkin tutumlarının değerlendirilmesi. Doktora Tezi, İstanbul Üniversitesi, İstanbul, Türkiye.

Rogers, A.E., Wei-Ting, H.S., Linda, D., Aiken, L.H., Dinges, D.F. (2004). The working hours of hospital staff nurses and patient safety. Health Affairs, 23, 202-212.

Sayek, F. (2011). Hasta güvenliği: Türkiye ve Dünya. 1th ed. Baskı, Ankara Türk Tabipleri Birliği Yayınları.

Sexton, J.B., Helmreich, R.L., Neilans, T.B., Rowan. K, Vella, K., Boyden. J., Roberts, P.R., Thomas, E.J. (2006). The Safety Attitudes quetionnaire: psychimetric properties, benchmarking data and emerging research. BMC Health Services Research, 6, 1-10.

Özmen, S., Başol, O. (2010). Hasta Güvenliği Kültürü: Bursa'da Özel Bir Hastane Uygulama Örneği. In: Demir M, Güler H, Öztürk A, Önder Ö,Beylik U, editors. II. Uluslararası Sağllkta Performans ve Kalite Kongresi Bildiriler Kitabi; , 28 April - 01 May 2010; Ankara,Türkiye: Baydan Ofset. pp.81-97.

WHO. 2005. Draft guiddlines for adverse event reporting and learning systems. Erişim 10.07.2013. http://www.who.int/patientsafety/events/05/Reporting Guidelines.pdf

Göçmen Z. Ameliyathane hemşirelerinin ameliyathane hemşireliği oryantasyon programı içeriğine ilişkin görüşleri, Cumburiyet Üniversitesi Hemşirelik Yülesekokulu Dergisi, 8: 12-24.

$\begin{array}{lllll}\text { WHO. 2013. Safe Surgery Saves Lives FAQ. } & \text { Erişim } \\ \text { 10.07.2013.http://www.who.int/patientsafety/safesurgery/faq_introduction/en/ } & \end{array}$

Table 1. Demographic characteristics of surgical nurses ( $\mathrm{n}=123)$

\begin{tabular}{|c|c|c|c|c|c|}
\hline Characteristics & n $(\%)$ & $\begin{array}{l}\text { Safety attitude scale } \\
\text { (Total score) } \overline{\mathbf{x}} \pm \text { SD }\end{array}$ & Test & P-value & $\begin{array}{l}\text { Significant } \\
\text { difference }\end{array}$ \\
\hline \multicolumn{6}{|l|}{ Age group } \\
\hline 18-29 year ${ }^{a}$ & 45 (36.6) & $54.68 \pm 13.91$ & \multirow{4}{*}{$\begin{array}{l}K W=8 . \\
605\end{array}$} & \multirow{4}{*}{$(s d: 2) 0.014$} & \multirow{4}{*}{$\mathrm{a}<\mathrm{b}, \mathrm{c}$} \\
\hline $30-39$ year $^{\text {b }}$ & $66(53.7)$ & $60.84 \pm 12.11$ & & & \\
\hline $40-49$ year $^{c}$ & $12(9.8)$ & $66.20 \pm 12.94$ & & & \\
\hline Gender & & & & & \\
\hline Female & $91(74.0)$ & $59.74 \pm 13.16$ & \multirow[b]{2}{*}{$t=.882$} & \multirow[b]{2}{*}{ (sd: 121) 0.380} & \\
\hline Male & $32(26.0)$ & $57.33 \pm 13.74$ & & & \\
\hline
\end{tabular}


Şahin, A., Ayhan, F., \& Kurşun, Ş. (2015). Evaluation of surgical nurses' attitudes concerning patient safety. International Journal of Human Sciences, 12(1), 1537-1546. doi: 10.14687/ijhs.v11i1.2879

\section{Education}

\section{MVHS $^{\mathrm{a}}$}

$$
38(30.9) \quad 58.88 \pm 13.39
$$

Associate degree

$$
33(26.8)
$$

$$
57.18 \pm 11.96
$$

$$
F=.633 \quad(s d: 2 / 120 / 122)^{*}
$$

Bachelor :gree/higher ${ }^{c}$

$$
52(42.3)
$$

$60.50 \pm 14.09$

W: Kruskal Wallis test (further analyses: Mann Whitney U test with Bonferroni Correction and Tukey)

t: $\mathrm{t}$-test in independent groups $=$ test for the significance between two means

F: One-way analysis of variance in the independent groups (further analysis: Tukey)

* Between group degrees of freedom /in group degrees of freedom / total degrees of freedom are given respectively.

Table 2. Professional characteristics of surgical nurses ( $\mathrm{n}=123$ )

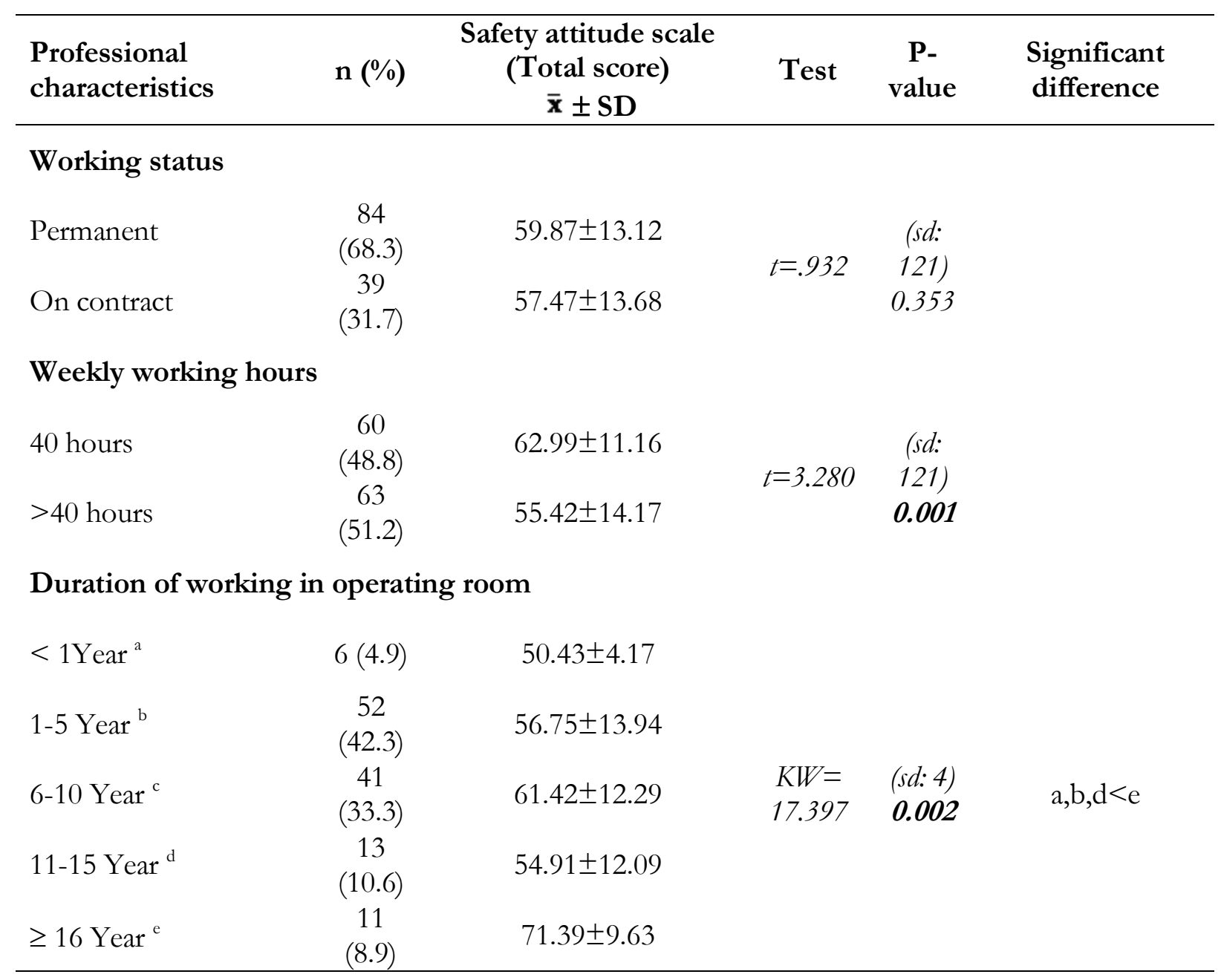




\section{Voluntary to work in operating room}

$\begin{array}{lllll}\text { Yes } & 105(85.4) & 58.98 \pm 13.16 & & \\ & & & U=935.0 & .943 \\ \text { No } & 18(14.6) & 59.87 \pm 14.43 & & \end{array}$

\section{Having adequate Resting}

$\begin{array}{ccccc}\text { Yes } & 45(36,0) & 62.46 \pm 13.93 & & (s d: 121) \\ \text { No } & 78(63,4) & 57.18 \pm 12.60 & t=2.154 & \mathbf{. 0 3 3}\end{array}$

\section{In-service-training}

$\begin{array}{lllll}\text { Yes } & 97(78.9) & 62.05 \pm 11.90 & & \\ \text { No } & 26(21.1) & 48.14 \pm 12.65 & & \end{array}=565.0 \quad .000$

Trained for patient safety

\begin{tabular}{ccccc} 
Yes & $82(66.7)$ & $61.13 \pm 13.05$ & & (sd: 121$)$ \\
No & $41(33.3)$ & $55.07 \pm 13.01$ & $t=2.433$ & $\mathbf{. 0 1 6}$ \\
\hline
\end{tabular}

Table3. Scores of safety attitude questionnaire for surgical nurses

\begin{tabular}{|c|c|c|c|c|}
\hline \multicolumn{2}{|c|}{ Scale and sub-dimensions } & $\overline{\mathbf{x}} \pm \mathrm{SD}$ & Minimum & Maximum \\
\hline \multicolumn{2}{|c|}{ SAQ total score } & $59.11 \pm 13.29$ & 21.12 & 86.64 \\
\hline \multirow{6}{*}{ 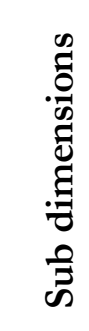 } & Team collaboration & $66.03 \pm 15.66$ & 25.00 & 98.21 \\
\hline & Work satisfaction & $69.07 \pm 24.44$ & .00 & 100.00 \\
\hline & Opinion about administration & $56.56 \pm 22.37$ & .00 & 100.00 \\
\hline & Safe environment & $63.16 \pm 16.41$ & 17.65 & 97.06 \\
\hline & Working conditions & $61.18 \pm 23.00$ & .00 & 100.00 \\
\hline & Stress level assessment & $42.12 \pm 16.82$ & 8.33 & 79.17 \\
\hline
\end{tabular}

